\title{
A NEW METHOD OF REDUCING DISLOCATION
}

\section{OF CERVICAL VERTEBR $A .{ }^{\prime}$}

\author{
By G. L. WALTON, M.D.,
}

Instructor in Diseases of the Nerrous System. Harvard University; Physician to Neurological Department, Massachusetts General Hospital.

DER ERSONAL experience has led me to believe that dislocation of cervical vertebræ, without fatal re. sults, is by no means of rare occurrence. Besides the eight cases which I publishcd in $1889^{\circ}$ and $\mathrm{I} 890,{ }^{3} \mathrm{I}$ had seen seven more, and had been communicated with regarding an eighth, making a total of sixteen, up to the publication of an article on the subject in 1892." In that publication a method of reduction was suggested which was theoretically correct, as shown by the manipulation of the vertebræ and by experiments upon the cadaver, made by Dr. Richardson and myself.

A case has recently occurred in the Massachusetts General Hospital, in which the practical success of the method was demonstrated upon a patient by Dr. Beach. This case will be reported by him later, so that I refrain from going into the details, but its success justifies me in recalling the subject here.

The commonest form of dislocation, without fatal re. sults, is the unilateral form, in which an articular process slips over the one below, causing the head to cant to one side and to twist so as to produce a similar position to that assumed in torticollis, the diagnostic feature being the immobility of the head in its new position, combined

\footnotetext{
' Read before the American Neurological Association, July, I893.

"Dislocation of Cervical Vertebra ; Five Cases; Recovery without Operation.-Journal of Nervous and Mental Disease, I889; also Boston Medical and Surgical Journal, March 21, I889.

${ }^{3}$ Dislocation of Cervical Vertebra without Fatal Results.-Bostone Medical and Surgical Journal, May 8, I8go.

${ }^{4}$ Dislocation of Cervical Vertebre.-International Clinics, 1892, Sec. ond Series, II., p. 207.
} 
with laxity of the muscles, the contraction of which would have produced the deformity, while those on the opposite side are put upon the stretch.

The method, the success of which has been established as far as one case can do so, is as follows:

Supposc the left artieular process of one vertebra has slipped forward over the eorresponding articular process of the vertebræ below and fallen into the depression anterior to that proeess. This turns the face to the right and bends the head over toward the left, as in spasm of the left sterno-cleido-mastoid. No amount of extension will remove the vertebre from its new position in the the slightest degree, as has been often shown; nor will rotation be available until the depressed articular process is raiscl. The proper method is simply, therefore, to first raise this process, then rotate. This can be accomplished only by extending the head obliquely backward toward the right, using the transverse process on the right as a fulcrum. "The ligaments," which have held the vertebræ firmly in its faulty position, make no opposition to this movement, so that no force is required to first elevate in this way, and then to rotatc to the proper position.

In bilateral dislocation it is quite probable that this maneurre, carried ont first on one side, then on the other, will meet with success. Indeed, this is probably the movement made involuntarily by the patient himself in a case of bilateral dislocation forward, occurring at the Massachusetts Gcneral Hospital several years ago, in the service of Dr. Warren. In this case attempts at reduetion by extension were unsuccessful, but spontaneous recovery oceurred through museular movement, produced while cold water was being poured upon the patient's back, the patient meantime sitting in a warm bath. In this case the existing paralysis of all extremities disappeared with great rapidity, and perfect recov-

"The muscles of the neck may be disregarded, the liganents alone holding the vertebrac firmly, as shown by the experiments upon the cadaver, in which all muscles were removed. 
DISLOCATION OF CERVICAL VERTEBRAE. 6i $\mathrm{i}$

ery followed. This case shows that direction-not force-is the key to reduction, as does also the case occurring in the practice of Dr. D. W. Hodgkins, of East Brookfield, who wrote me that reduction, already attcmpted without success, occurred accidentally, while the patient was being carried to the house, through the inharmonious movement of Dr. Hodgkins, who carried the head, and those who carried the trunk and limbs.

Again, in a former case, upon which Dr. Beach was about to attempt reduction, involuntary movements of the patient under ether brought about the desired result without outside interference.

'These facts led me to the study, of which this method is the outcome, a method which seems certainly worthy of reiteration, as the practitioner is liable to meet these cases at any time, they being certainly much more common than has been hitherto supposed, the diagnosis probably being not infrequently overlooked, either through lack of acquaintance on the part of the practitioner with the characteristic features, or through hesitation in making a diagnosis of so serious import in cases where no paralysis exists, such paralysis often failing to appear through the ample lumen left for the passage of the cord in the unilateral form of dislocation.

Epilepsy anā Comitial Anbulatory Automatism in a Negro.-(Dr. Raucon, Archives de Medecine Navale, f. 59, I 893). A negro, twenty-five years old, a native of Soudan, has four or five epileptic fits a day, which are frequently followed by an excursion of several days duration from his village, of the details of which, on his return, he has not preserved the slightest memory. At these moments, he goes straight ahead, and when consciousness returns, believes he has just come from home or has slept away the time, recalling neither where he has been nor what he has seen.

E. N. B. 